\title{
Multiple criteria decision making approaches for forest sustainability (case study: Iranian caspian forests)
}

\begin{abstract}
The aim of this research is to investigate the sustainability of economic, social and environmental aspects in Iranian Caspian forests. To do so, questionnaires were used for data collection. The questionnaires were distributed among the forestry experts in Guilan province, north of Iran. Analytic Hierarchy Process (AHP) and the Network Analysis (ANP) were used for prioritizing the indicators of sustainable forest management. Investigated criteria and indicators are derived from the Near Middle East Process. The Expert Choice and Super Decision software were used for data analysis. The results of this study showed that the wood products sub-criterion and conservation of biological diversity have been known the most important criteria in the sustainable forest management in the study area using of AHP and ANP. Furthermore, the priorities of the other indicators are different in AHP and ANP. This could be due to the reciprocity relations in the ANP and this method has more strengths than AHP.
\end{abstract}

Keywords: multi criteria decision making, sustainable forest management, iranian caspian forests
Volume 2 Issue 2 - 2018

\author{
Zohreh Mohammadi, Soleiman Mohammadi \\ Limaei \\ Department of Forestry, Faculty of Natural Resources, \\ University of Guilan, Iran
}

Correspondence: Soleiman Mohammadi Limaei, Department of Forestry, Faculty of Natural Resources, University of Guilan, Sowmeh Sara, P.O.Box-1 I44, Iran, Tel +989 I 3364599, Email limaei@guilan.ac.ir

Received: November 22, 2017 | Published: April 13, 2018
Abbreviations: AHP, analytic hierarchy process; ANP, analytical network process; SFM, sustainable forest management; SDI, sustainable development indicators; FAO, food and agriculture organization; ITTO, international tropical timber organization; UNEP, united nations environmental programme; MCDM, multi criteria decision making; PSA, pressure state response.

\section{Introduction}

The sustainable forest management (SFM) is now defined as "stewardship and use of forests and forest land in a way, and at a rate, that maintains their biodiversity, productivity, generation capacity, vitality, and their potential to fulfil now and in the future, relevant ecological, economic, and social functions at local, national, and global levels. ${ }^{1}$ The concept of SFM derived impetus from several waves of global developments, including the 1992 United Nations Conference on Environment and Development held in Rio de Janeiro, Brazil, the Intergovernmental Panel on Forests (1995-1997), the Intergovernmental Forum on Forests (1997-2000), and the United Nations Forum on Forests that came into being in 2001. One of the most applied ways of assessing sustainability is the indicator approach. Indicators can provide useful information on the status and trends of sustainable development and such information can then be used by decision-makers. Sustainable development indicators (SDI) include economic, ecologic and social dimensions. Experts from several fields have participated in numerous meetings to compile lists of criteria and indicators (C \& I). Lists of potential indicators have been compiled regionally, nationally and internationally, with immense investments of time and effort. ${ }^{2}$ The parameters of SFM gained further clarification, thanks to C\& I initiatives such as the Montreal Process and the Pan-European Process, as well as a host of forest certification schemes. ${ }^{3}$ However, using C\&I has become a common approach to assess or evaluate aspects of SFM. They are custom tools within political (e.g., ITTO, MCPFE, Near East Process, Montreal Process,
Tarapoto Proposal, UNEP-FAO Dry Zone Africa) and certification initiatives. ${ }^{4}$ Among these initiatives, the Near East Process (1996) was developed in Cairo by the Food and Agriculture Organization and the United Nations Environmental Programme (UNEP), of which Iran is also a member country. ${ }^{5} \mathrm{C} \& \mathrm{I}$ could provide a framework for the formulation of policy options, help to advance international cooperation and also provide an assessment of the positive and negative changes in forest conservation and management at different levels. ${ }^{6} \mathrm{FAO} / \mathrm{UNEP}$ Expert Meeting on criteria and indicators for SFM for countries in the region identified 7 criteria and 65 indicators for sustainable forest management at the regional and national levels. Criteria including: (1) Extent of forest resources, (2) Conservation of biological diversity in forest areas, (3) Health, vitality and integrity, (4) Productive capacity and functions, (5) Protective and environmental functions, (6) Maintenance and development of socio-economic functions and conditions, (7) The legal and institutional frameworks. ${ }^{5}$ Multi criteria decision making (MCDM) techniques incorporate both quantitative and qualitative criteria to a decision problem. ${ }^{7}$ Among the various MCDM techniques proposed, the Analytic Hierarchic Process (AHP) and the Analytic Network Process (ANP) are two methods proposed by Saaty et al. ${ }^{8,9}$ Wolfslehner et al. ${ }^{10}$ compared two different multi-criteria analysis approaches: AHP with a hierarchical structure and the ANP with a network structure. Comparisons were made for evaluating sustainable management strategies at forest managementunit level by using a criteria and indicators approach based on the Pan-European guidelines for SFM. AHP and ANP are used to compare four different strategic management options with a set of six criteria and 43 indicators. Differences in evaluation results between AHP and ANP are discussed, as well as strengths and weaknesses of both approaches for SFM. Needs and demands are derived for successful future applications in forestry decision-making. Wolfslehner et al. ${ }^{11}$ arranged indicators for SFM in a Pressure-State-Response (PSR) framework at forest management unit level. This framework links pressures on the environment caused by human activities with changes 
of environmental state (condition) parameters. Forest management also responds to these changes by instituting environmental and economic measures to reduce pressures and restore natural resources. The ANP is utilized to evaluate the performance of four management strategies with regard to the PSR framework on SFM. Priorities of indicators and alternatives are modelled with the ANP resulting from the interconnections to other indicators and their respective cumulative importance. The approach allows for more detailed information on the network of human influences and their impacts on forest ecosystems and goes beyond the limitations of flat-dimensioned indicator sets. Vacik et al. ${ }^{12}$ to characterize the sustainability of possible forest management alternatives, employ the Analytical Network Process (ANP), the enlarged version of the AHP. This comparison between AHP and ANP for approaching sustainability in forest management by means of a set of indicators can also be seen in the works of Wolfslehner et al. ${ }^{10,11,13}$. Balana et al. ${ }^{14}$ several MCDM methods are compared to evaluate the sustainability in communal forests in Ethiopia. Tajbar et al. ${ }^{15}$ implemented the criteria and indicators for SFM in India on a pilot basis since 2000. The initiative, known as the Bhopal-India process, has over the years endeavored to formulate a working framework for the achievement of the goals of sustainability social-cultural benefits for the communities, enhancing their quality of life. Jalilova et al. ${ }^{16}$ Developed criteria and indicators for evaluating sustainable forest management in Kyrgyzstan using AHP method. There are a few studies determining the Criteria and Indicators $(\mathrm{C}$ \& I) for sustainable forest management in Iran. ${ }^{17-21}$ The aim of this research is to investigate the sustainability of economic, social and environmental aspects in Iranian Caspian forests and to prioritize the indicators related to the sustainable forest management using AHP and the ANP.

\section{Material and methods}

\section{Study area}

The study area was Shafarood watershed which is located in the west of Guilan province in north of Iran with an area of $394 \mathrm{~km}^{2} .{ }^{22}$ The area of the forests under supervision of Shafarood Forest Company is about 135 thousand ha (Figure 1).

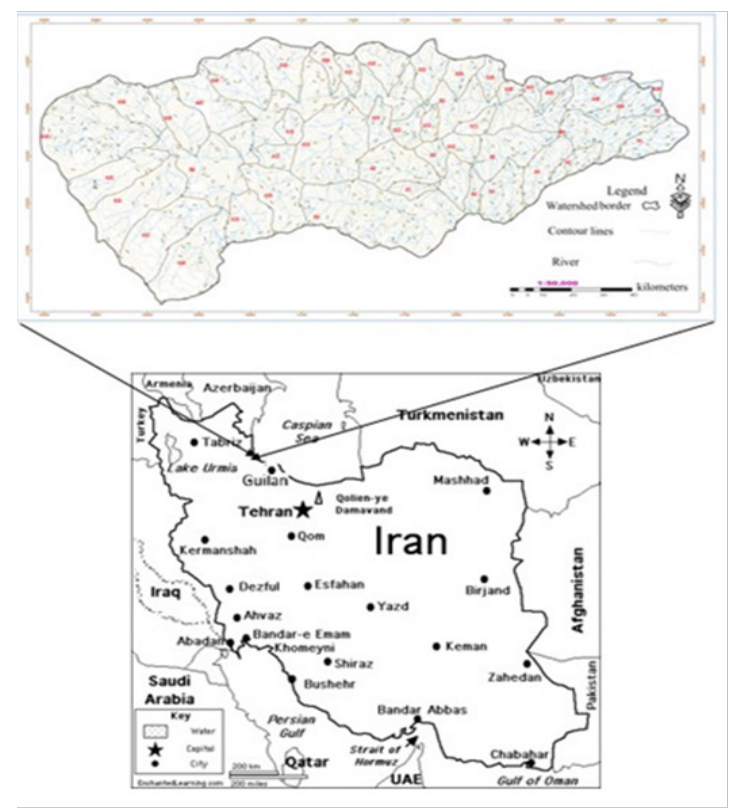

Figure I Study area, Shafarood forest in north of Iran..$^{23}$
Table I Criteria and sub-criteria (indicator) for SFM in Near East Process. ${ }^{5}$

\begin{tabular}{|c|c|c|}
\hline Criteria & $\begin{array}{l}\text { Sub-criteria ( } \\
\text { indicator) }\end{array}$ & Abbreviation \\
\hline \multirow{3}{*}{ Economic } & Value of wood products & Wood pro \\
\hline & $\begin{array}{l}\text { Value of non-wood } \\
\text { products }\end{array}$ & Non wood \\
\hline & $\begin{array}{l}\text { Value of recreation \& } \\
\text { hunting }\end{array}$ & Rec \& Hun \\
\hline \multirow{3}{*}{ Social } & Employment & Employ \\
\hline & $\begin{array}{l}\text { Presence of indigenous } \\
\text { people }\end{array}$ & Presence \\
\hline & $\begin{array}{l}\text { Improvement of life quality } \\
\text { of forest dwellers }\end{array}$ & Improve \\
\hline \multirow{3}{*}{ Environmental } & Extent of forest resources & Extent \\
\hline & $\begin{array}{l}\text { Protective and } \\
\text { environmental functions }\end{array}$ & Protect \\
\hline & $\begin{array}{l}\text { Conservation of biological } \\
\text { diversity }\end{array}$ & Conser \\
\hline
\end{tabular}

\section{Method}

In order to do this research, questioner was used and it was designed based on criteria and indicators of Near East Process (Table 1). The AHP and ANP methods were used for analysis. In this approach, at least 12 questionnaires should be filled by experts. ${ }^{24}$ The questionnaires were filled by 30 experts in Guilan's Natural Resources Organization.

\section{Analytic hierarchy process (AHP)}

AHP is a decision-making technique which can be used to analyze and support decisions which have multiple and even competing objectives. To do this, a complex problem is divided into a number of simpler problems in the form of a decision hierarchy. ${ }^{25}$ Once the hierarchy has been established, a pair wise comparison matrix of each element within each level is constructed. Participants can weight each element against each other within each level, which is related to the levels above and below it, and mathematically tie the entire scheme together. AHP is often used to compare the relative suitability of a small number of alternatives concerning the overall goal. AHP allows some small inconsistency in judgment. The reason is that human is not always consistent. The ratio scales in AHP are derived from the principal Eigen vectors and the consistency index is derived from the principal Eigen value. To start with AHP, first a hierarchy structure is required. While building the hierarchy tree, including more than nine elements in any objective group is not considered since it is cognitively challenging for humans to evaluate more than nine factors at a time. When the model is built, the next step is to evaluate the elements by making pair wise comparisons. ${ }^{26}$ The hierarchical structure evaluation at this research is shown in Figure 2. It uses a multi-level hierarchical structure of objectives, criteria, sub-criteria. The pertinent data are derived using a set of pair wise comparisons. These comparisons are used to obtain the weights of importance of the decision criteria, and the relative performance measures of the alternatives in terms of each individual decision criterion. If the comparisons are not perfectly consistent, then it provides a mechanism for improving consistency. ${ }^{27}$ The consistency ratio values of all comparisons were lower than 0.10 , which indicated that the use of the weights was suitable. ${ }^{28}$ 


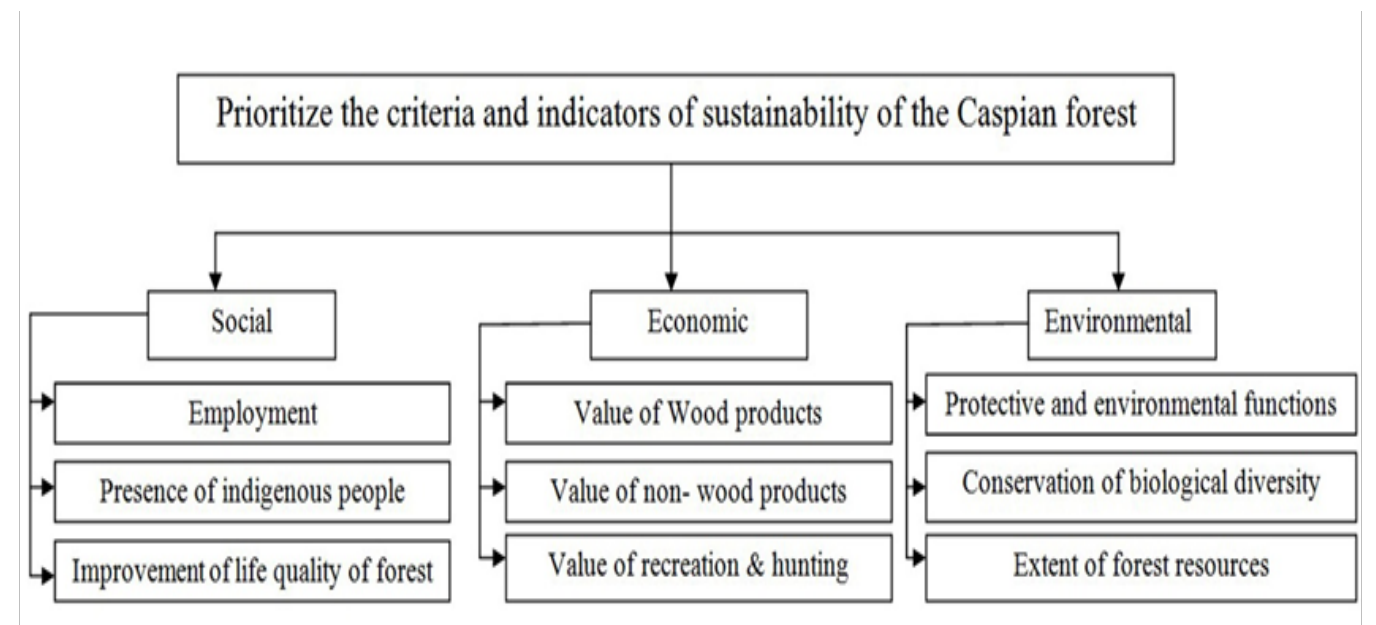

Figure 2 AHP methods in this study.

\section{Analytic network process model (ANP)}

The ANP retains the idea of criteria, which are now named clusters due to terminology reasons, but replaces the hierarchy of the AHP by a network structure. With ANP, there is a need to indicate all dependences among indicators, and determining the direction of the influence. Connections can be set among elements within a cluster (i.e., Interdependence) and between clusters (i.e., Interdependence). In a cumulative view, a cluster is connected to another when at least one of its elements is connected to at least one element of the other cluster (Figure 3). Elements and clusters can thus appear as sources, which are origins of paths of influence, as sinks, which are destinations of paths of influence, and as cycles or loops, indicating feedback on themselves, represented by the direction of the arrows. ${ }^{29}$ The ANP questionnaire is presented in the form of pair wise comparison between the elements in the cluster to compare how big the magnitude of the effect is and how big the difference is. The scale used is a numerical scale $1-9 .{ }^{30}$ The model structure of ANP is relatively complex and the computation process is also relatively complex, which is hard to be applied to the practice without the assistance of the professional software. Super Decision software had successfully made ANP computing programmed; it can compute any ANP models and express the computing result completely. In order to analyze the data, Super Decision software, version 1.6. was used in this research.

Figure 3 ANP structure at this study.

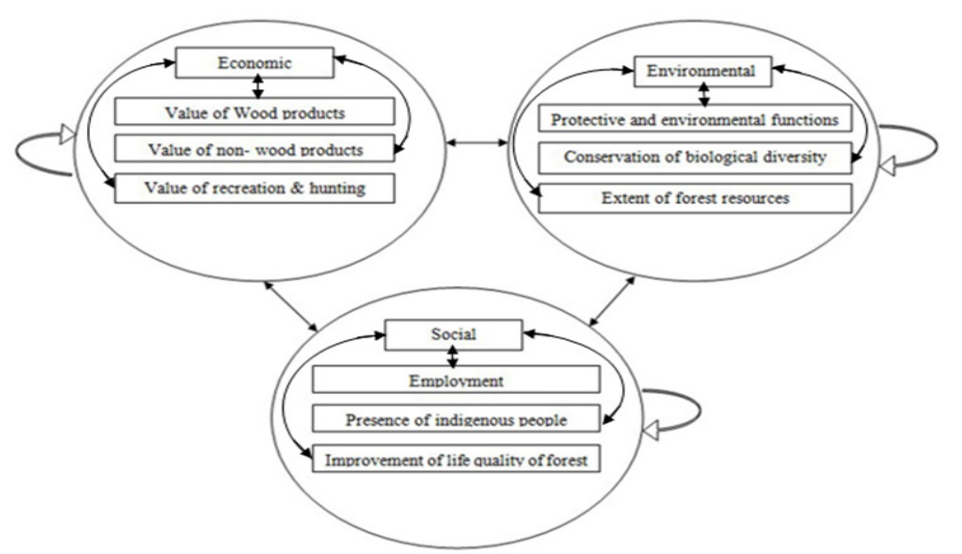

In this study, the inconsistency ratio was less than 0.1 ; it was accepted as compatible judgments. In the next step, super matrix has been investigated in order to achieve the final priority. Pair wise comparison for both weighting the clusters (i.e., criteria) and for estimating the direction and importance of between elements is conducted and numerically presented as ratio scales in a so-called super matrix. ${ }^{29}$ The super matrix represents priority of an element in the left of the matrix on an element at the top of the matrix, with respect to a particular control criterion. ${ }^{31}$ 


\section{Results}

\section{Results of AHP}

Results of data analysis show that the criteria such as economic, environmental and social are respectively important in determining the criteria for sustainable forest management at the study area (Figure 4).

The weights and inconsistency are shown in Figure 4. The economic criterion is more important and its weight is 0.550 . The second important criterion is environmental and its weight is 0.275 . Finally, the less important criterion is social value and its weight is 0.175 . The inconsistency rate is 0.0 . According to the AHP's rule of thumb, if the value of inconsistency ratio is smaller or equal to 0.1 , the inconsistency is acceptable. Figure 5 shows that results of the final weight of each sub-criterion compared to the favourable criterion. The value of wood products and conservation of biological diversity sub-criteria are the most important indicators in determining the subcriterion for sustainable forest management in the study area.

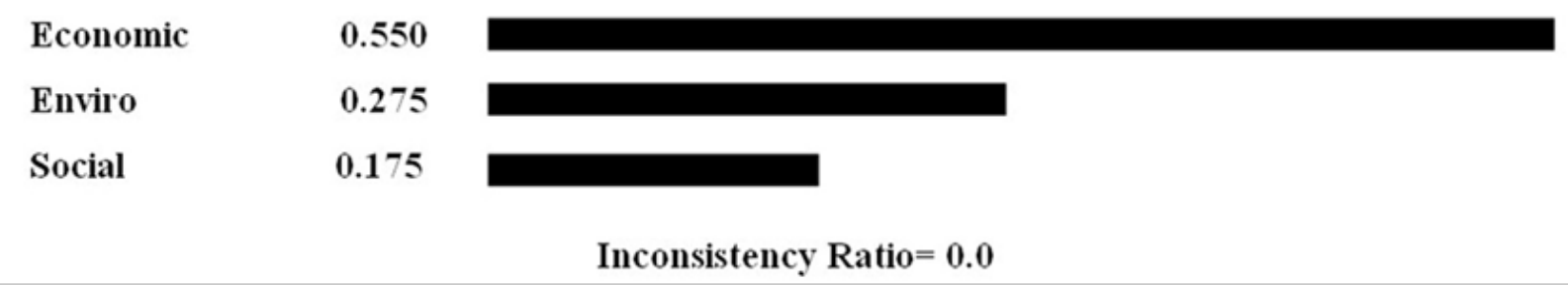

Figure 4 Weight of criteria using AHP method (inconsistency ratio= 0.0 ). The abbreviations of economic, environmental and social criteria in the software were economic, environ and social, respectively.

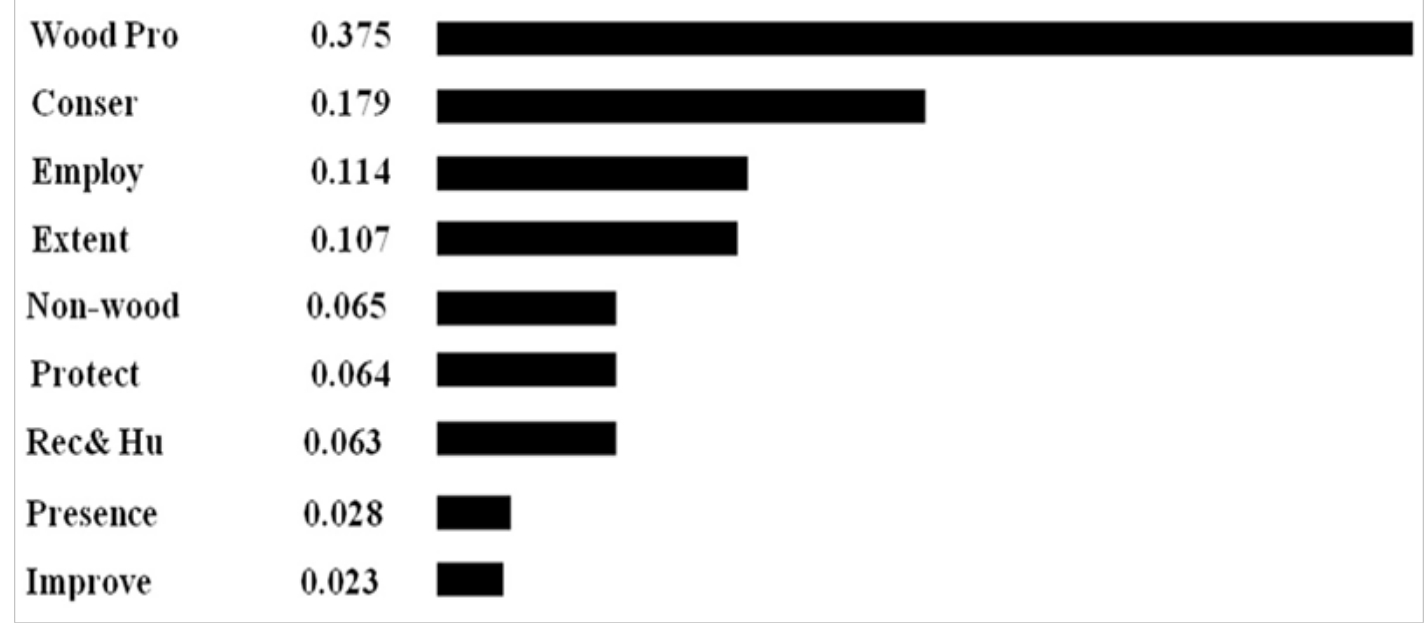

Figure 5 Weight of sub-criteria using AHP method at expert choice software (inconsistency ratio $=0.0 \mathrm{I}$ ). The abbreviation of sub criteria of Value of wood products, Value of non- wood products, Employment, Presence of indigenous people, Improvement of life quality of forest dwellers, Extent of forest resources, Protective and environmental functions and Conservation of biological diversity in the software were Non wood, Rec \& Hun , Employ, Presence, Improve, Extent, Protect and Conser respectively.

\section{Results of ANP}

The relationship between elements is examined reciprocity using ANP method Due to ignoring the comparison of clusters, the values of super matrix with and without the weights is are identical. Results of limit matrix calculations indicated that according to the final weight of the constituent elements in ANP model, the most important criterion for SFM were economic, environmental and social criterion with the final weights of $0.5469,0.2754,0.1748$, respectively. The results of the weighted limit super matrix showed that the value of wood products, employment and the conservation of biological diversity have the highest weight in the economic, social and environmental criterion, respectively. There is the reciprocity relations in ANP approach.
Hence, the ratio of the criteria to sub-criteria is considered. Also the results showed that the economic criteria has the highest weight in the sub-criteria of the values of wood products, non-wood products, recreation and hunting, employment, presence of indigenous people and improvement of life quality of forest dwellers sub-criteria (Table 2 ). The final results of the reciprocity comparison of ANP showed that the sub-criteria including the value of wood products, conservation of biological diversity, extent of forest resources, employment, protective \& environmental function, value of non-wood products, value of recreation \& hunting, presence of indigenous people and improvement of life quality of forest dwellers are important priorities, respectively. These results show similarity to the results of AHP (Figure 6). 
Table 2 The weighted super matrix of criteria and indicators

\begin{tabular}{|c|c|c|c|c|c|c|c|c|c|c|c|c|c|}
\hline & $\begin{array}{l}\text { Wood } \\
\text { pro }\end{array}$ & $\begin{array}{l}\text { Non } \\
\text { wood }\end{array}$ & Rec\&Hun & Employ & Presence & Improve & Extent & Protect & Conser & Economic & Social & Enviro & Goal \\
\hline $\begin{array}{l}\text { Wood } \\
\text { pro }\end{array}$ & 0 & 0 & 0 & 0 & 0 & 0 & 0 & 0 & 0 & 0.7365 & 0 & 0 & 0 \\
\hline $\begin{array}{l}\text { Non } \\
\text { wood }\end{array}$ & 0 & 0 & 0 & 0 & 0 & 0 & 0 & 0 & 0 & 0.1335 & 0 & 0 & 0 \\
\hline Rec\&Hun & 0 & 0 & 0 & 0 & 0 & 0 & 0 & 0 & 0 & 0.1299 & 0 & 0 & 0 \\
\hline Employ & 0 & 0 & 0 & 0 & 0 & 0 & 0 & 0 & 0 & 0 & 0.6886 & 0 & 0 \\
\hline Presence & 0 & 0 & 0 & 0 & 0 & 0 & 0 & 0 & 0 & 0 & 0.1724 & 0 & 0 \\
\hline Improve & 0 & 0 & 0 & 0 & 0 & 0 & 0 & 0 & 0 & 0 & 0.1388 & 0 & 0 \\
\hline Extent & 0 & 0 & 0 & 0 & 0 & 0 & 0 & 0 & 0 & 0 & 0 & 0.3061 & 0 \\
\hline Protect & 0 & 0 & 0 & 0 & 0 & 0 & 0 & 0 & 0 & 0 & 0 & 0.5099 & 0 \\
\hline Conser & 0 & 0 & 0 & 0 & 0 & 0 & 0 & 0 & 0 & 0 & 0 & 0.1838 & 0 \\
\hline Economic & 0.7206 & 0.6235 & 0.5141 & 0.6911 & 0.349 & 0.5578 & 0.2036 & 0.3333 & 0.1406 & 0 & 0 & 0 & 0.5496 \\
\hline Social & 0.1333 & 0.1733 & 0.3343 & 0.2367 & 0.4815 & 0.3182 & 0.0991 & 0.0333 & 0.0988 & 0 & 0 & 0 & 0.1748 \\
\hline Enviro & 0.1459 & 0.203 & 0.1514 & 0.072 & 0.1694 & 0.1239 & 0.6972 & 0.3333 & 0.7605 & 0 & 0 & 0 & 0.2754 \\
\hline \multirow[t]{10}{*}{ Goal } & 0 & 0 & 0 & 0 & 0 & 0 & 0 & 0 & 0 & 0 & 0 & 0 & 0 \\
\hline & \multicolumn{3}{|c|}{ Wood Pro } & 0.375 & & & & & & & & & \\
\hline & \multicolumn{3}{|c|}{ Conser } & 0.181 & & & & & & & & & \\
\hline & \multicolumn{3}{|c|}{ Extent } & 0.108 & & & & & & & & & \\
\hline & \multicolumn{3}{|c|}{ Employ } & 0.107 & & & & & & & & & \\
\hline & & \multicolumn{2}{|c|}{ Non-wood } & 0.065 & & & & & & & & & \\
\hline & & \multicolumn{2}{|c|}{ Protect } & 0.064 & & & & & & & & & \\
\hline & & \multicolumn{2}{|c|}{ Rec\& Hu } & 0.063 & & & & & & & & & \\
\hline & & \multicolumn{2}{|c|}{ Presence } & 0.027 & & & & & & & & & \\
\hline & & \multicolumn{2}{|c|}{ Improve } & 0.021 & & & & & & & & & \\
\hline
\end{tabular}

Figure 6 Weight of sub-criteria using ANP method at Super Decision software (inconsistency ratio $=0.0$ ).

\section{Discussion}

The aim of this research is to investigate the criteria and indicators of SFM in Iranian Caspian forests, north of Iran. AHP and ANP techniques were used in order to prioritize the criteria and indicators. AHP and ANP have been applied in a wide variety of areas as a useful and practical multi-criteria decision-making tool. ${ }^{32}$ The results of this study showed that the economic criterion have been the most important in AHP method and the Value of wood products sub-criterion and the conservation of biological diversity have been the most important criteria in both AHP and ANP methods. The value of wood products is important in study area because according to present inexact statistics half of the forests in the north of Iran are commercial, ${ }^{33}$ an average of 4.2 million $\mathrm{m}^{3}$ wood of these forests were exploited each year as commercial and non-commercial products. ${ }^{34}$ In all development planning in Caspian forests, the conservation and extension of the forests in the north of Iran are known as the most important and the most valuable forest ecosystems and the most important source of timber production. ${ }^{33}$ Hyrcanian forest contain the most important and significant natural habitats for in-situ conservation of biological diversity, including those containing threatened species of outstanding universal value from the point of view of science or conservation. ${ }^{35}$ An overview on the status of biodiversity profiles at local to regional scale suggests that it is at its highest state of vulnerability, due to increased exploitative anthropogenic activities and climate change induced losses. Thus there is a need for biodiversity conservation in order to sustain the ecological integrity and enhance livelihood support system as identified in the millennium development goals. ${ }^{36}$ Accordingly, the conservation of biological diversity has been known the second sub-criterion in the sustainable development of forests. Groselj et al. ${ }^{37}$ ranked and evaluated the effects of forest management scenarios on human communities, landscapes, and the development of forest services, and to achieve a balance between the economic, 
environmental, and social and culture uses of forests in Pohorje, Slovenia. Their results reveal that maximum attention needs to be paid to preserve the nature and biodiversity. The aim of "biodiversity preservation and protection of natural values" is biodiversity conservation, natural value protection, and protection of the landscape. In this study, biodiversity conservation is also important in forest sustainability. However, the priorities of other indicators are different in two processes that, due to the reciprocity relations in the ANP process whereas this method has more strengths than AHP. Wolfslehner et al. ${ }^{10}$ compared two different multi-criteria analysis approaches such as AHP and ANP in Austrian forests. Comparisons are made for evaluating the sustainable management strategies at forest management-unit level using a criteria and indicators approach based on the Pan-European guidelines for SFM. The indicator of the value of wood products in Shafarood Forests is the most important indicator. Goushegir et al. ${ }^{17}$ used the AHP methods for monitoring forest management plans in Kheyrud Forest at north of Iran. Their results showed that two indicators such as the value of wood products and conservation of biological diversity are the most important indicators for achieving the sustainability. The results of our study are similar to their results. Compared with similar studies, Balana et al. ${ }^{14}$ applied a multi-criteria decision analysis tool to evaluate forest management problems in the northern province of Tigray, Ethiopia. Acquainting local people with adequate environmental knowledge and raising local awareness about the long-term consequences of environmental degradation ranked first among the set of sustainability criteria. Jalilova et al. ${ }^{16}$ applied a combination of a top-down and bottom-up approach with multi-criteria analysis (MCA) to identify a set of C\&I with different groups of stakeholders in selected sites at the forestry management unit level (leshoz). A final set of C\&I that consist of seven criteria and 45 indicators has been identified for evaluating sustainable forest management (SFM) in the walnut-fruit forests in south Kyrgyzstan. The results showed that Forest health and vitality was found to be the most important criterion, while the maintenance of forest biodiversity was found to be the least prioritized among other criteria. The result of this study is in contrast with the results of our study, Because Indicators in forest management depend on local, often site-specific, environmental factors such as forest type and topography, local economic and social considerations and priorities. The criteria at forest management unit level are likely to be identical or very similar to those defined at national level, although they are more flexible. Thus, they must be mutually compatible to help ensure complementarily over the country. ${ }^{38}$ Goleij et al. ${ }^{21}$ defined appropriate criteria and indicators for sustainable forest management through a network of multi criteria decision analysis methods in the Nav-e Asalem forests in Guilan province, Iran. The results showed that the area of natural forests with healthy regeneration, tree marking of seed stock and balance between growth and harvesting are the most important indicators for sustainable forest management in local scale across the study site. In recent studies the criterion priority for sustainability forest could vary at different study areas due to location and environmental conditions.

\section{Conclusion}

This paper has presented some important criteria and indicators, which supports participatory decision making for forest management and policy and thus can aid forest managers in the decision making process when designing a forest management plan. In the future studies we recommend to increase questionnaires in order to assess the forest sustainability and the results will be more realistic

\section{Acknowledgements}

None.

\section{Conflict of inertest}

Authors declare there is no conflict of interest.

\section{References}

1. Soili NH. The Changing Governance of Renewable Natural Resources in Northwest Russia. UK: Ashgate Publishing; 2009. 265 p.

2. Rosenström U. Sustainable development indicators: much wanted, less used? Finland: Edita Prima; 2009. p. 1-77.

3. Carnus JM, Parrotta J, Brockerhoff EG, et al. Planted Forests and Biodiversity. In: UNFF Intersessional Experts. New Zealand: Maximising the Role of Planted Forests in Sustainable Forest Management; 2003. p. 24-30.

4. Rametsteiner E, Simula M. Forest certification-an instrument to promote sustainable forest management? Journal of Environmental Management. 2003;67(1):87-98

5. FAO. Biosafety issues related to biotechnologies for sustainable agriculture and food security. Secretariat Note to the $8^{\text {th }}$ Regular Session of the Commission on Genetic Resources for Food and Agriculture. Italy: FAO; 1999. p. 1-72.

6. Kondrashov LG. Russian Far East forest disturbances and socioeconomic problems of restoration. Forest Ecology and Management. 2004;201(1):65-74.

7. Aragonés-Beltrán P, Chaparro-González F, Pastor-Ferrándo JP, et al An ANP-based approach for the selection of photovoltaic solar power plant investment projects. Renewable and Sustainable Energy Reviews. 2010;14(1):249-264.

8. Saaty TL. The Analytic Hierarchy Process. Planning, Priority Setting, Resource Allocation. USA: McGraw-Hill; 1980. 283 p.

9. Saaty RW. The analytic hierarchy process-what it is and how it is used Mathematical Modelling. 1987;9(3-5):161-176.

10. Wolfslehner B, Vacick H, Manfered J. Application of the analytic network process in multi-criteria analysis of sustainable forest management. Journal of Forest Ecology and Management. 2005;207(1-2):157-170.

11. Wolfslehner B, Vacik H. Evaluating sustainable forest management strategies with the Ana-lytic Network Process in a Pressure-StateResponse framework. Journal of Environmental Management. 2008;88(1):1-10.

12. Vacik H, Wolfslehner B, Seidl R, et al. Integrating the DPSIR approach and the Analytic Network Process for the assessment of forest management strategies. In: Reynolds KM, Thomson AJ, Köhl M, Shannon MA, Ray D, Rennolls K, editors. Sustainable forestry: from monitoring and modelling to knowledge management and policy science. UK: CABI; 2007. p. 393 411.

13. Wolfslehner B, Vacik H. Mapping indicator models: from intuitive problem structuring to quantified decision-making in sustainable forest management. Ecological Indicators. 2011;11(2):274-283.

14. Balana BB, Mathijs E, Muys B. Assessing the sustainability of forest management: An application of multi-criteria decision analysis to community forests in northern Ethiopia. Journal of Environmental Management. 2010;91(6):1294-1304. 
15. Tajbar SR, Menaria BL, Dugaya D, et al. Developing criteria and indicators for evaluating sustainable forest management: A case study in Kyrgyzstan. Forest Policy and Economics. 2012;21:32-43.

16. Goushegir SZ, Feghhi J, Mohajer MR, et al. Criteria and indicators of monitoring the sustainable wood production and forest conservation using AHP (Case study: Kheyrud Educational and Research Forest). African Journal of Agricultural Research. 2009;4(10):1041-1048.

17. Zandebasiri M, Parvin T. Investigation on Importance of Near East Process's criteria and indicators on sustainable management of Zagross forests (Case study: Tange Solak Water Catchment, Kohgiloye and Boyer Ahmad province). Iranian Journal of Forest and Poplar Research. 2012;20(2):204-216.

18. Seyd SZ, Moayeri MH, Mohammadi J. Introducing the Criteria and Indicators of Measuring Stand Structure in Sustainable Forest Management. Journal of Conservation and Utilization of Natural Resources. 2012;2:25-38.

19. Kaji HS, Jafari A, Yarali N. An assessment of forest management sustainability in Do-Polan district, Chaharmahal and Bakhtiari Province, Iran. Iranian Journal of Forest and Poplar Research. 2015;23(3):409501.

20. Goleij A, Navroodi IH, Limaei SM. Determining the criteria and indicators for sustainable forest management (Case study: Nav-e Asalem, Guilan province). Iranian Journal of Forest and Poplar Research. 2016;24(1):187-176.

21. Hassanimehr SS, Kohi S. Identifying potential of river basins as suitable eco-tourism spots: a case study of shafarood river, Guilan, Iran. Environmental Based Territorial Planning. 2011;4(13):105-118.

22. Shafarood Forest Management Plan. Shafarood watershed schedule. Iran: Rangelands and Watershed management organization; 2015. 171 p.

23. Karami S. Analysis of factors influencing in selecting species for landscaping border rail routes (Case Study: subway of SadeghieEkbatan). MSc thesis, Natural Resources Department. Iran: Tehran University; 2000. 89 p.

24. Saaty TL. Decision making with the analytic hierarchy process. International Journal of Services Sciences. 2008;1(1):83-98.

25. Alanbay O. ERP selection using expert choice software. In: Levy J, editor. Proceeding of International Symposium on the Analytic Hierarchy Process (ISAHP). USA: Multi-criteria Decision Making; 2005. p. 1-10.
26. Putrus P. Accounting for intangibles in integrated manufacturing (nonfinancial justification based on the analytical hierarchy process). Information Strategy. 1990;6:25-30.

27. Eastman JR. IDRISI Kilimanjaro: Guide to GIS and Image Processing. USA: Clark Laboratories, Clark University; 2003. 328 p.

28. Saaty TL. Decision making with independence and feedback: The Analytic Network Process. USA: RWS Publications; 2001.

29. Wibisono GA, Darwanto D. Strategy of Strengthening Social Capital of Farmer Group in Agricultural Development. JEJAK: Jurnal Ekonomi Dan Kebijakan. 2016;9(1):61-80.

30. Jaafari A, Najafi A, García-Melón M. Decision-making for the selection of a best wood extraction method: An analytic network process approach. Forest Policy and Economics. 2015;50:200-209.

31. Sipahi S, Timor M. The analytic hierarchy process and analytic network process: an overview of applications. Management Decision. 2010;48(5):775-808.

32. Marvie Mohadjer MR. Silviculture. Iran: University Tehran Press; 2006. $388 \mathrm{p}$.

33. Limaei MS, Lohmander P. Stumpage Prices in the Iranian Caspian Forests. Asian Journal of Plant Sciences. 2007;6(7):1027-1036.

34. UNESCO. Hyrcanian Forest (Caspian Forest). 2007.

35. Botteroa M, Comino E, Duriavig M, et al. The application of a Multicriteria Spatial Decision Support System (MCSDSS) for the assessment of biodiversity conservation in the Province of Varese (Italy). Land Use Policy. 2013;30(1):730-738.

36. Groselj P, Hodges DG, Strin LZ. Participatory and multi-criteria analysis for forest (ecosystem) management: A case study of Pohorje, Slovenia. Forest policy and economics. 2016;71:80-86.

37. Islam R, Siwar CS, Islamil M, et al. Criteria and indicators for sustainable forest management in Malaysia. American Journal of Environmental Sciences. 2010;6(3): 212-218. 